\title{
突起付きパンチを用いた張力下の打抜きによる 高強度薄鋼板の打抜き穴広げ性の改善
}

\author{
高橋 雄三* 堀岡 聡** 河野 治*
}

小原 昌弘*** 潮田 浩作****

\section{Improvement in Stretch Flange Ability of High-Tensile-Strength Steel Sheets by Piercing under Tension Using Humped Bottom Punch}

\author{
Yuzo TAKAHASHI*, Satoshi HORIOKA*, Osamu KAWANO*, \\ Masahiro OHARA*** and Kohsaku USHIODA****
}

(Received on November 8, 2011)

\begin{abstract}
To meet the requirements for the weight reduction of automobiles, high-tensile-strength steel sheets have been applied extensively to the manufacture of auto parts. But their relatively lower press formability has obstructed their further application, and it is strongly demanded that the stretch flange ability of such steel sheets be increased, and cracks that occur when stretching edges during the press forming of such steel sheets be suppressed. Thus the authors have carried out a study to improve the stretch flange ability of high-tensile-strength steel sheets by optimizing the punching method and obtained the following conclusions. Work hardening on a pierced edge is mainly caused by deformation by the punch motion while shearing the material. By attaching a hump of certain shape at the bottom of the punch, the ductile fracture in the material caused by the punch corner is accelerated by the hump's effect to increase stress triaxiality, which reduces the extent of total deformation through shearing, thereby improving the stretch flange ability of the material.
\end{abstract}

Key words: shearing, piercing, bore expanding test, high-tensile-strength steel sheet.

\section{1. 緒 言}

自動車の軽量化，燃費低減のニーズにより，自動車への 高強度鋼板の適用が進んでいる. 高強度鋼板は多くの場合, より低強度の鋼板と比べ伸びや穴広げ性等の成形性が劣位 であるため，その適用に当たってはプレス成形での割れを 抑制することが重要である。足廻り部品を初めとした多く の部品の成形において打抜き端面に加工を加える伸びフラ ンジ成形が行われる例が多く見られ，それらへの高強度鋼 板の適用に当たってはそのような打抜き穴広げ成形での端 面割れを回避することが重要である。

打抜き穴広げ性に関しては，素材の延性を改善すること と打抜き工程で生じる打抜き端面のひずみ（加工硬化）を 抑制することが重要であることが指摘されている ${ }^{1)}$.

*新日本製鐵(株) 大分技術研究部 $\bar{\top} 870-0992$ 大分市大字西ノ洲一番地 Oita R\&D Laboratory, Nippon Steel Corporation,

1 Oaza Nishinosu Oita 870-0992, Japan.

** (株) N•TEC 大分 ₹ 870-0992 大分市大字西ノ洲一番地 $\mathrm{N} \cdot$ TEC Oita Co.Ltd, 1 Oaza Nishinosu Oita 870-0992, Japan.

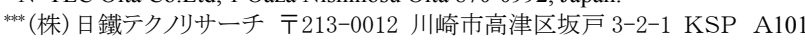
Nippon Steel Techno Research, KSP A101, 3-2-1 Sakado, Takatsuku, Kawasaki City, Kanagawa 213-0012 Japan.

俎制新日本製鐵(株) 技術開発本部 干293-8511 千葉県富津市新富 20-1 Technical Development bureau, Nippon Steel Corporation, 20-1 Shintomi, Futtsu City, Chiba 293-8511, Japan.
鋼板の打抜き技術（せん断加工技術）による穴広げ性改 善に向け，これまで，レーザー切断 ${ }^{2)}$, 削り抜き法 ${ }^{3)}$ 二段 打抜き技術 ${ }^{4)}$ 等が提案されているが，これらはいずれも通 常の打抜きに対して端面の加工ひずみを低減することによ り端面の成形性を改善したものと推察される.

しかし，これらの方法はいずれも，設備の維持管理の煩 雑さ，金型製作の時間，コストの増加，工程の増加等を要 するため, コスト増加の要因を招くといった実用上好まし くない点も有するものと思われる.

著者らは，以上を鑑みて上記のような実用上好ましくな い点を生じることなく，打抜き後の端面の加工ひずみを低 減し，打抜き穴広げ性の改善を図る打抜き技術の開発に向 けた研究を行った，特に，打抜きパンチに所定の突起を付 け打抜き時に素材に張力を生じさせることによりパンチ肩 からのき裂の発生・伝播を促進し，打抜き端面のひずみの 低減と端面の成形性を改善する効果を見出し, その原因に 関する考察を行った．従来から削り抜き法 ${ }^{3)}$ に見られるよ うに打抜きパンチ形状を工夫して打抜き穴広げ性を改善す る研究例は見られるが，それはほぼ通常の打抜きを行った 後にその時点の加工硬化部を削り落とすことにより最終的 な端面の加工ひずみを抑制するものである，本研究のよう 
に，パンチ形状を工夫し，打抜き時のき裂の発生・伝播自 体を制御することにより打抜き端面の加工ひずみを低減す る研究は他に例がない.

本報告では，通常の打抜き工程における端面の加工硬化 メカニズムの調査, および FEM 解析による突起を打抜き パンチに付けた場合のき裂の発生の促進効果の推定および それによる打抜き穴広げ性の改善効果の検証を行った結果 について述べる。

\section{2. 実験方法}

\section{1 打抜き穴広げ試験}

Table 1 に示す鋼を用いて, Table 2, Fig.1 に示す条件で 打抜き穴広げ試験を行い，限界穴広げ率入を測定した。打 抜き穴広げ試験では，初めに試験片に $\phi 20 \mathrm{~mm}$ の打抜き穴 を開け, 次に打抜きパンチと同じ方向から穴広げパンチ(頂 角 $60^{\circ}$ 円錐パンチ) を打抜き穴に押し込み，端面上のき裂 が板厚を貫通した時点の穴径の拡大率を限界穴広げ率入と した。この打抜き穴広げ試験条件は打抜き穴径を除けば日 本鉄鋼連盟規格(JFS T1001)に等しい. 一種類の材料の限界 穴広げ率入は，3 回の打抜き穴広げ試験を行い，その試験 值の平均值として求めた.

打抜きパンチの形状は, Fig.2 に示すようなタイプ 1, タ イプ 2 の 2 タイプとした. タイプ 1 は通常の打抜きパンチ （平底）であり, タイプ 2 は, 打抜き端面の加工硬化の低 減を意図してパンチ底面に突起を付けたパンチである．突 起の効果については後に詳細に解析を行う. また, 突起に よる素材の反りが生じないように打抜き時はしわ押えで試 験片のフランジ部を強くダイに固定した。 また，打抜き後 の端面の加工硬化を調べるために，打抜き後に穴広げ試験 を行わず，そのまま初期穴の圧延方向端面の断面を埋め込

Table 1 Steels used for this study

\begin{tabular}{|c|c|c|c|}
\hline $\begin{array}{c}\text { Thickness } \\
/ \mathrm{mm}\end{array}$ & $\begin{array}{c}\text { YP } \\
/ \mathrm{MPa}\end{array}$ & $\begin{array}{c}\mathrm{TS} \\
/ \mathrm{MPa}\end{array}$ & $\begin{array}{c}\text { T.El } \\
/ \%\end{array}$ \\
\hline 3.6 & 701 & 771 & 23 \\
\hline
\end{tabular}

Table 2 Test condition

\begin{tabular}{|l|l|l|}
\hline \multirow{4}{*}{ Piercing } & Punch diameter & $20 \mathrm{~mm}$ \\
\cline { 2 - 3 } & Punch speed & $300 \mathrm{~mm} / \mathrm{sec}$ \\
\cline { 2 - 3 } & Clearance & $\begin{array}{l}0.45 \mathrm{~mm} \\
\text { (Specimen thickness } \times 0.125)\end{array}$ \\
\cline { 2 - 3 } & $\begin{array}{l}\text { Blank holder } \\
\text { control }\end{array}$ & $\begin{array}{l}\text { Position control } \\
\text { (to contact specimen) }\end{array}$ \\
\cline { 2 - 3 } & Lubricant & Used (oil) \\
\hline \multirow{5}{*}{$\begin{array}{l}\text { Hole } \\
\text { expanding }\end{array}$} & Punch type & $\begin{array}{l}\text { Conical punch } \\
\text { (Top angle }=60^{\circ} \text { ) }\end{array}$ \\
\cline { 2 - 3 } & Punch speed & $0.4 \mathrm{~mm} / \mathrm{sec}$ \\
\cline { 2 - 3 } & $\begin{array}{l}\text { Blank holding } \\
\text { force }\end{array}$ & $10 \mathrm{kN}$ \\
\cline { 2 - 3 } & $\begin{array}{l}\text { Direction of } \\
\text { punch motion }\end{array}$ & Same as piercing punch \\
\cline { 2 - 3 } & Lubricant & Used (oil) \\
\hline
\end{tabular}

$*$ Specimen size $=150 \mathrm{~mm} \times 150 \mathrm{~mm}$

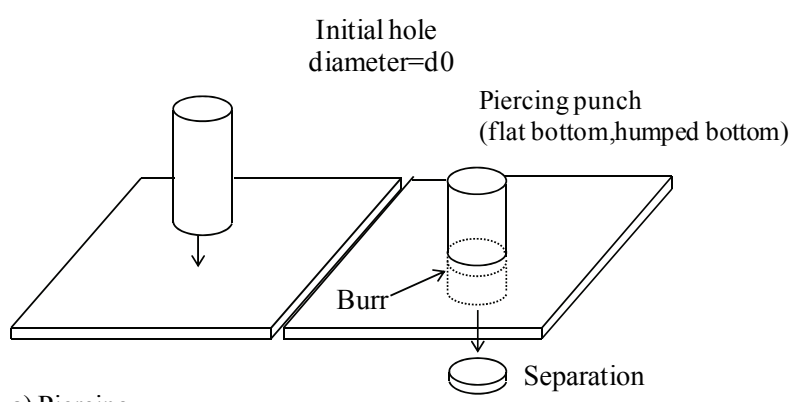

a) Piercing 命 Reversing specimen

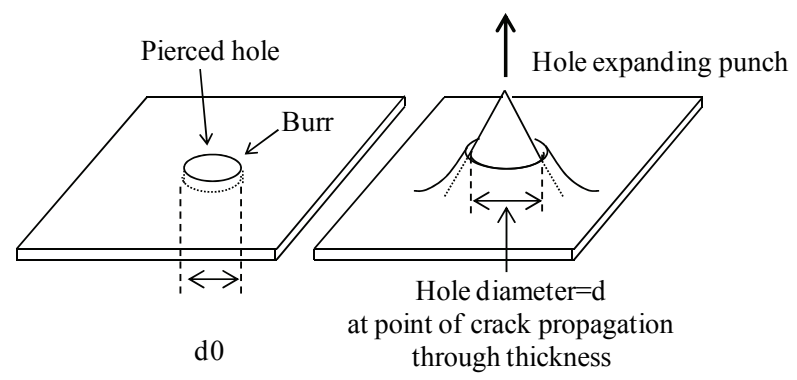

b) Hole expanding

Fig. 1 Procedure of hole expansion test

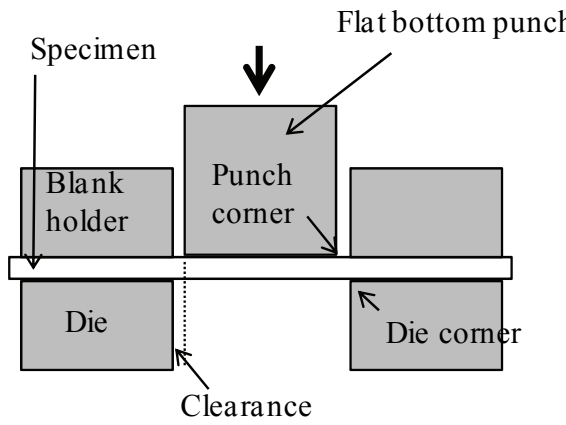

a) Type1.CONVENTIONAL PUNCH

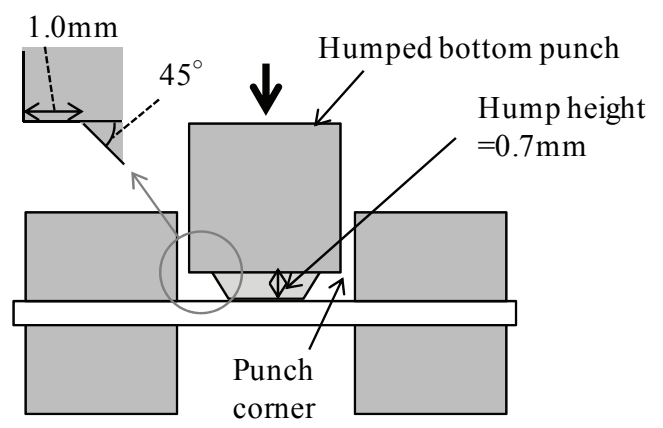

b) Type2. HUMPED BOTTOM PUNCH

Fig. 2 Two types of piercing punches used in this study

み，端面形状の観察，および端面の硬さ測定 $(\mathrm{HV} 1 \mathrm{~kg})$ を実 施した。硬さ測定は初期穴の圧延方向断面において，ダイ 肩位置 (ダイ肩 R の R 止まり(Curving point)の位置 (Fig.3)) を起点とした素材の板厚方向の線上で実施した。尚，パン チとダイの肩 R は打抜き後の素材のかえり(Burr)の根元部 分の形状から推定すると本試験ではそれぞれ約 $10 \mu \mathrm{m}$ ，約 $30 \mu \mathrm{m}$ であった。 
以上の 2 タイプのパンチを用いた打抜きを行った場合の パンチ肩（パンチ切刃）でのき裂の発生条件について考察 するため, 有限要素法による打抜き時の応力・ひずみの解 析を行った. 有限要素法解析は, 陰解法ソフト（MARC） を用い軸対称要素を用いて行った。計算に用いた材料特性 は Table 1 に示す鋼の特性とした。

\section{2 打抜き過程における加工硬化挙動の調査 (打ち抜き 途中停止試験)}

Table 1 の鋼を供試鋼として, 突起付きパンチおよび通常 パンチでの打抜き時の端面の加工硬化挙動を詳細に調べる ために，各々のパンチでの打抜き工程において，打抜きパ ンチが材料を分離するより前の過程（所定のせん断面長さ の段階）で停止し，次にパンチを引き抜いて，圧延方向端 面の断面を埋め込み, 打抜き端面の硬さ $(\mathrm{HV} 1 \mathrm{~kg})$ を測定し た. 硬さ測定は, 初期穴の圧延方向断面において, ダイ肩 位置( $\mathrm{R}$ 止まり)を起点とした素材の板厚方向の線上で行っ た.

\section{3. 試験結果および考察}

\section{1 打抜き工程における端面の加工硬化メカニズム}

打抜き後の端面ひずみの低減に向けて, まず通常パンチ での打抜き時に端面が加工硬化するメカニズムについて調 査した. Fig. 3 にタイプ 1 の通常パンチを用いて, 所定のス トロークまでパンチを移動し, その後パンチを抜いた場合 の端面 (断面) の形状を示す. 通常パンチでの打抜きでは, 初めの過程でパンチが素材をせん断し $(\mathrm{a}) \Rightarrow \mathrm{b}) \Rightarrow \mathrm{c})$ ), 次にパ ンチとダイの肩(Corner)からき裂が発生し, それらの中間で それらのき裂が会合し材料の分離に至る(d)).

今回の供試鋼をタイプ 1 の通常パンチで打抜いた場合, Fig.3 でせん断面の長さが $1.0 \mathrm{~mm}$ であることから， $1.0 \mathrm{~mm}$ のせん断面が形成された段階でパンチ・ダイの肩部近傍か らき裂が発生し, 分離に至っていることがわかる.

Fig.3 中に示す各段階の図中にダイ肩部を起点とした板 厚方向の直線（白線）上で硬さを測定した結果を Fig.4に 示す。これより, 打抜き端面の硬さは, せん断面が形成さ れる間（せん断開始〜せん断面 $1.0 \mathrm{~mm}$ の間）に大幅に増加 することがわかる。また，図中にはせん断面長さが同じ $1.0 \mathrm{~mm}$ の場合で，かつ材料の分離の直前および後の端面の 硬さ分布も示している. き裂伝播による硬さの増加は, ダ イ肩部(Corner)近傍, すなわち端面直下のごく浅い部分で見 られるものの, それ以外で確認されない.これより, 打抜 き端面の硬さの増加, すなわちひずみの蓄積はせん断面が 形成されている段階，すなわち材料がパンチとダイにより 塑性変形している段階で大半が生じていることがわかる.

したがって，打抜き穴広げ性の改善に向け打抜き端面の ひずみを低減するためには，打抜き時に打抜きパンチの肩 からのき裂の発生を促進し, より早期に破断面を形成させ, せん断面の形成段階を短くすることが有効である.

\section{2 パンチ肩先端の応力多軸度の推定}

次に打抜き時にパンチ肩でのき裂の発生を促進する条件 について考察を行った，打抜き時のパンチ肩でのき裂は肩 近傍での応力, ひずみの集中により延性破壊が生じること により発生するものと考えられる ${ }^{5)}$. 塑性加工における延 性破壊の発生条件は, 応力多軸度 $T$ を考慮した限界の相当

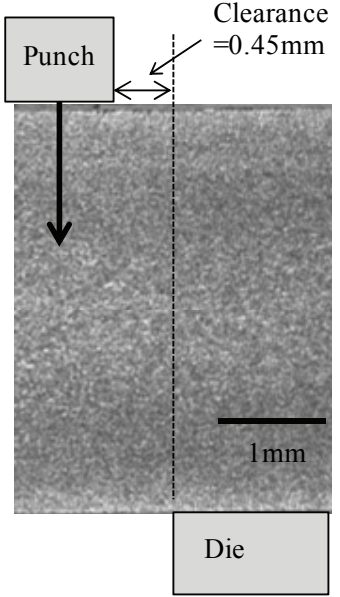

a) Before piercing

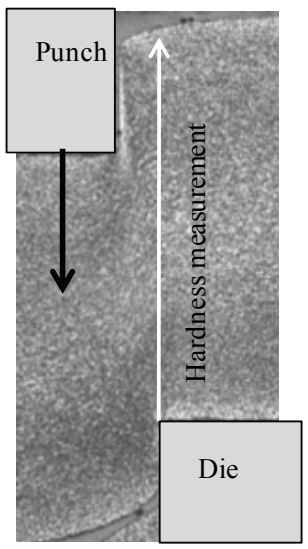

c) Shear surface $=1.0 \mathrm{~mm}$ (before separation)

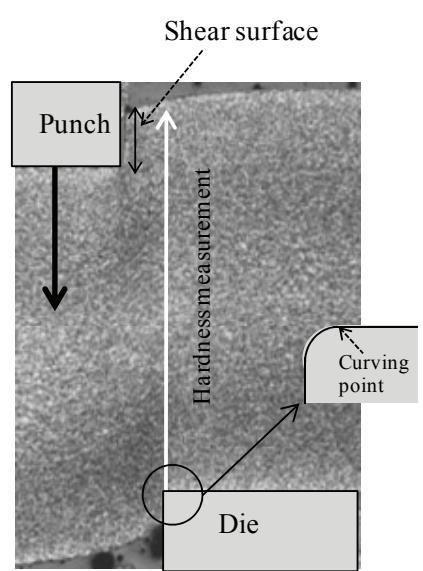

b) Shear surface $=0.5 \mathrm{~mm}$

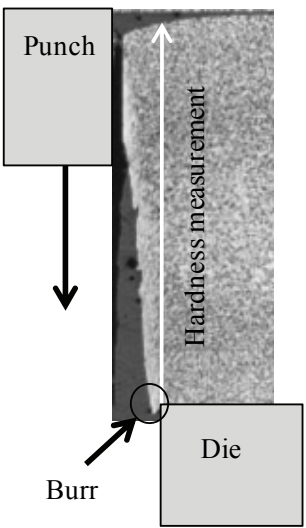

d) Shear surface $=1.0 \mathrm{~mm}$ (after separation)
Fig. 3 Piercing behavior as a function of punch stroke when type 1 punch is used

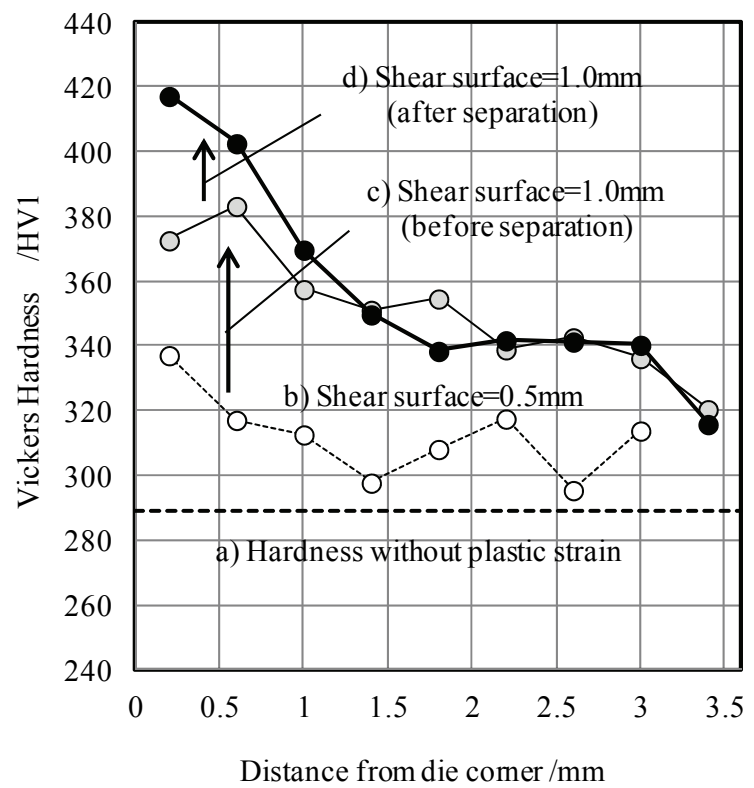

Fig. 4 Change of hardness during piercing

塑性ひずみ $\varepsilon_{f}$ により整理され ${ }^{6)}$ ，ひずみ集中部の応力多軸 度 $T$ を増加させることにより延性破壊限界の相当塑性ひず み $\varepsilon_{f}$ は低減することが知られており，式(1)が提唱されてい $ろ^{7)}$. 
$\varepsilon_{f}=\alpha e^{-\beta T}$

ここで, 係数 $\alpha, \beta$ は材料により定まる定数であり, $T$ は応 力多軸度であり, 式(2)で表わされる。

$$
T=\frac{\sigma_{m}}{\sigma_{e q}}
$$

ここで， $\sigma_{m}, \sigma_{e q}$ はそれぞれ平均応力, 相当応力であり, $\sigma_{1}, \sigma_{2}, \sigma_{3}$ を主応力として式(3), 式(4)で表わされる.

$\sigma_{m}=\frac{\left(\sigma_{1}+\sigma_{2}+\sigma_{3}\right)}{3}$

$\sigma_{e q}=\sqrt{\frac{\left(\sigma_{1}-\sigma_{2}\right)^{2}+\left(\sigma_{2}-\sigma_{3}\right)^{2}+\left(\sigma_{3^{-}} \sigma_{1}\right)^{2}}{2}}$

式(1)の関係が得られるのは, 応力多軸度 $T$ が高いほど相 当応力に対して平均応力が高いため体積膨張を伴う変形が 起きやすくボイドの発生が促進されるためと考えられる. したがって, パンチ肩部での引張応力成分を付加して応力 多軸度を増加させることによりパンチ肩でのき裂発生を促 進することができるものと考えられる，そこで，打抜きパ ンチに突起を付け，パンチ肩近傍の素材のひずみ集中部に 通常の打抜きパンチ以上の引張応力を加えた場合のパンチ 肩近傍の忘力多軸度 $T($ 式 $(1))$ ・相当塑性ひずみ $\varepsilon_{e q}$ を FEM 解 析により求め, 突起によるパンチ肩近傍での延性破壊の促 進効果を定量評価した.

Fig.2 に示すタイプ 1 およびタイプ 2 の形状の打抜きパン チを用いて前述(2.1)の打抜き条件で打抜きを行った場合の せん断部分の応力・ひずみ分布を求めた. FEM 解析は陰解 法(MARC)を用いて軸対称モデルを適用し, リメッシュ機 能を用いて行った. Fig.5, Fig.6 に両者のパンチで打抜く 際の相当塑性ひずみ, 平均応力の分布を示す. これより, パンチ〜ダイ間の材料の応力・ひずみ分布は, パンチが移 動するにつれ，いずれも増加することがわかる. 図中には パンチ肩近傍での延性破壊の発生について考察するため, パンチ肩近傍 $100 \mu \mathrm{m} \times 100 \mu \mathrm{m}$ の部分の平均の相当塑性ひ ずみ, 平均応力の值も示している. パンチ肩近傍に着目す ると, 相当塑性ひずみは突起付きパンチの場合と比べ大き な差はない, 一方, 平均応力は, 突起付きパンチの場合, 通常パンチと比べ特に大きい. これは突起による引張応力 が肩近傍に加わるためと考えられる.

Fig.7 に双方の場合のパンチ肩近傍 $100 \mu \mathrm{m} \times 100 \mu \mathrm{m}$ の部 分の平均の応力多軸度 (平均応力 / 相当応力) に対する相 当塑性ひずみ量の変化を示す. 図中には供試鋼を対象とし て求めた式 $(1)^{7)}$ にる延性破壊限界も示している。 その際 $\alpha=3.3, \beta=2.0$ とした. $\alpha$ はタイプ1のパンチでせん断した 場合せん断面長さが $1.0 \mathrm{~mm}$ の時にき裂が発生し破断面が 開始していることを参考に定め, $\beta$ は高強度鋼の測定例と して示されている平均的な值 ${ }^{8)}$ とした. 図では各プロット のせん断面長さも示している. これより, タイプ 1 の通常 パンチではせん断面長さが $1.0 \mathrm{~mm}$ の時にき裂が発生する

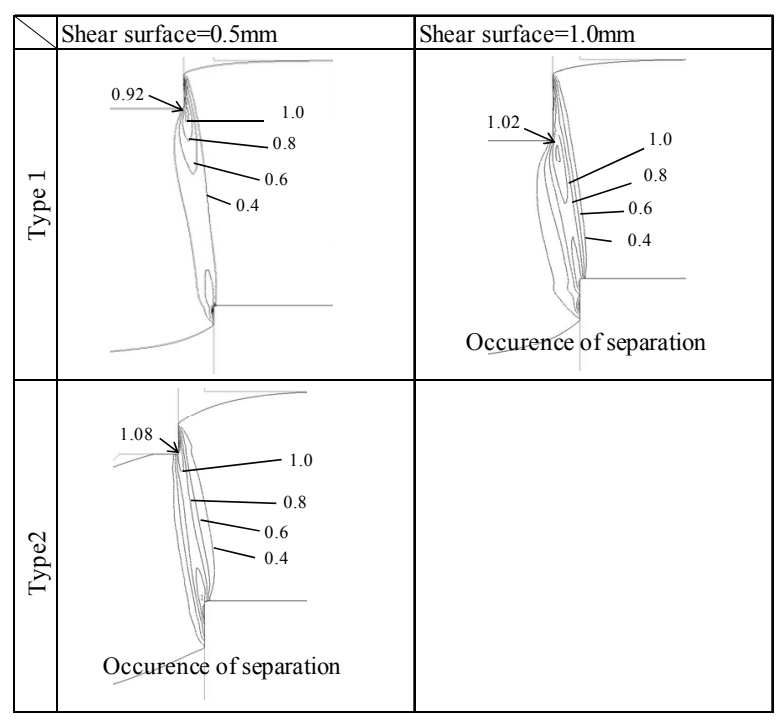

Fig. 5 Calculated distribution of equivalent strain (Values of equivalent strain are shown in figures)

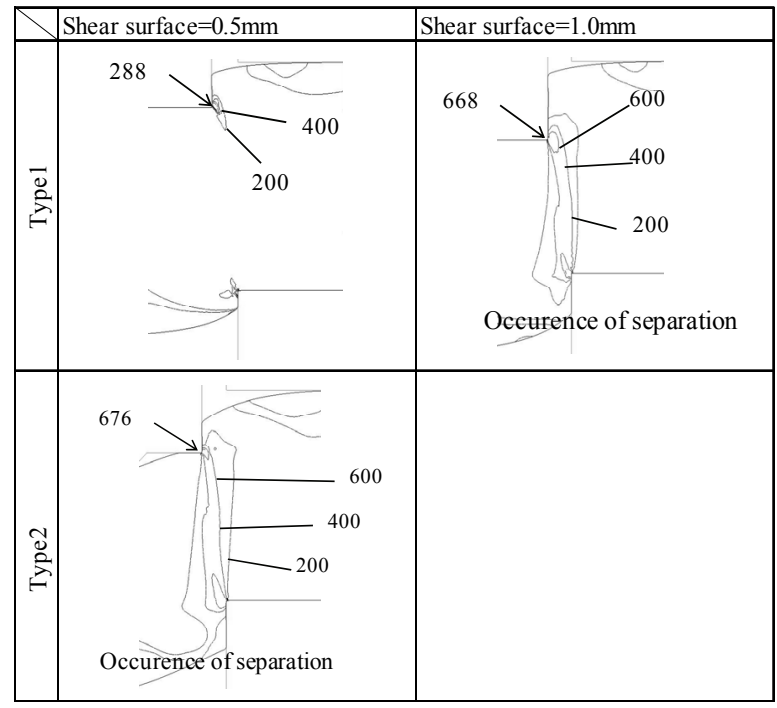

Fig. 6 Calculated distribution of mean stress (Values of mean stress are shown in figures in unit of $\mathrm{MPa}$ )

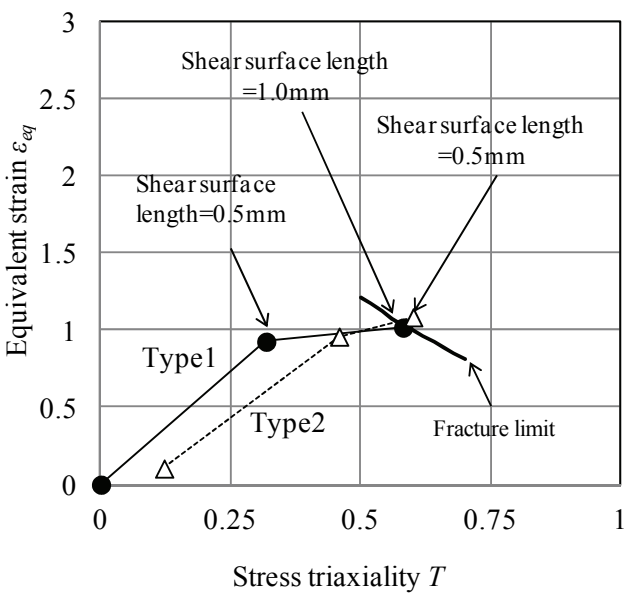

Fig. 7 Relationship between stress triaxiality and equivalent strain

のに対して, タイプ 2 の突起付きパンチではそれが $0.5 \mathrm{~mm}$ の時にき裂が発生することが推定される。したがって, 突 起付きパンチとすることにより，短いせん断面で，すなわ 
ち端面の加工硬化が小さい段階でパンチ肩より延性破壊が 生じることが推察される.

\section{3 突起付きパンチによる打抜き穴広げ性改善効果}

以上の考察に基づいて，次に突起付きパンチによる打抜 き端面ひずみの低減効果および打抜き穴広げ性の改善効果 を検証した. Fig.2 に示すタイプ 1 およびタイプ 2 の打抜き パンチを用い，前述（2.1）の条件で打抜き穴広げ試験を行 った．その場合の打抜き穴広げ率入を Fig.8 に示す。ここ で，打抜き穴広げ率入は 3 回の打抜き穴広げ試験にて評価 したが，その試験值に大きなばらつきは見られなかった。 突起付きパンチにより限界打抜き穴広げ率は $60 \%$ から 85\%まで，25\%改善されていることがわかる.

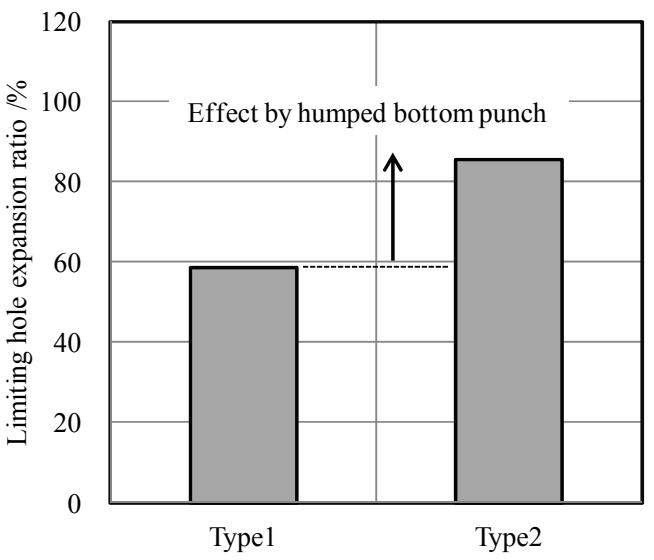

Fig. 8 Improvement of limiting hole expansion ratio by using humped bottom punch

Fig.9, Fig.10 に，それぞれタイプ1（通常パンチ）およ びタイプ 2 (突起付きパンチ) での打抜き後の断面形状, および硬さ分布を示している，硬さは，Fig.9 に白線で示す 端面表面から約 $70 \mu \mathrm{m} \sim 500 \mu \mathrm{m}$ にあるダイ肩線上で測定し た.これらよりタイプ 2（突起付きパンチ）の場合，タイ プ 1 (通常パンチ) と比べせん断面比率が低減しており, 同時に硬さも低減していることがわかる.

打抜き穴広げ性に対しては，端面直下の塑性ひずみや， 端面全体(打抜き影響のある部分全体)のひずみ等の打抜き

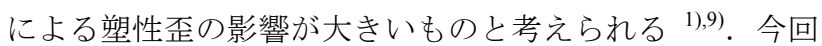
の場合，双方の打抜きパンチのケースともに端面直下の塑 性ひずみ量は, 端面表面で延性破壊が既に生じているので, 素材の破壊条件に依存した一定の值であることが予想され

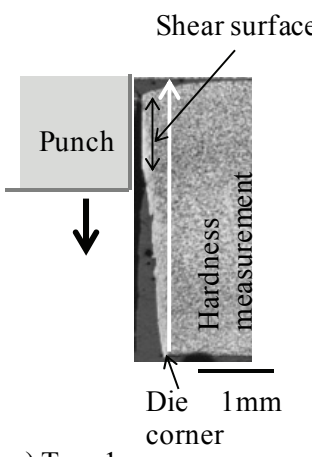

a) Type 1

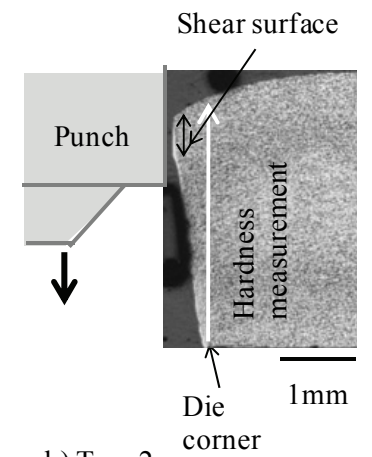

b) Type2
Fig. 9 Shape of cross section of pierced edge

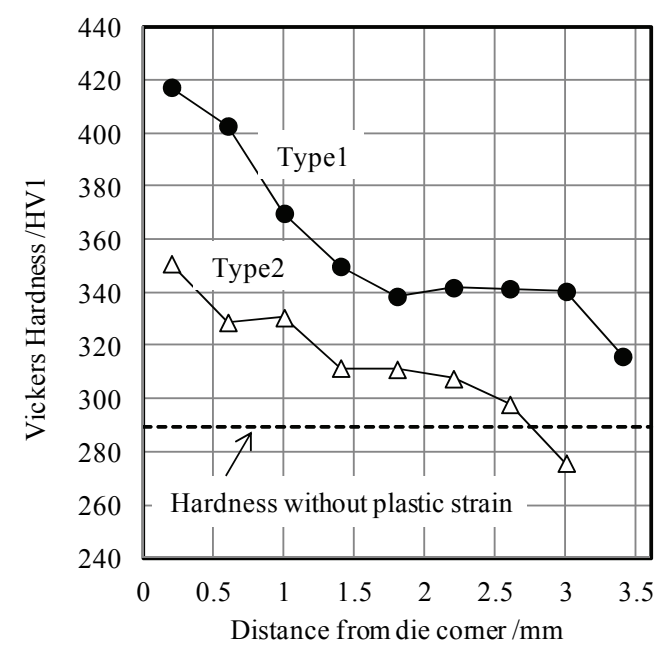

Fig. 10 Hardness distribution on pierced edge

る．突起付きパンチによる打抜き穴広げ性の改善の理由は Fig.9 に示すようにある程度端面から深い位置の塑性ひず みの低減効果によるものと考えられる。

\section{4. 結 言}

自動車の軽量化や衝突安全性改善に向けた高強度鋼板の 適用の障害となっている打抜き穴広げ成形での割れ抑制に 向け，実用上の課題を生じることなく打抜き穴広げ性を改 善寸る打抜き技術の開発を目指し，以下が判明した。

1)所定の突起の付いた打抜きパンチを用いることにより，

打抜き後の端面ひずみを低減し，穴広げ性を改善するこ とができる，同パンチによる端面ひずみの低減は，突起 の効果により打抜き時のパンチ肩からのき裂発生を促進 し, せん断面形成段階の塑性変形による端面近傍へのひ ずみ蓄積を抑制した効果によると考えられる。

2)突起によるパンチ肩からのき裂発生の促進効果は突起に よる引張応力により肩近傍の応力多軸度が増加し延性破 壊の発生が促進されたため得られたものと考えられる.

\section{参 考 文 献}

1) 中川威雄 - 吉田清太 : 理化学研究所報告, 44-3(1968), 150-162.

2) 白沢秀則 - 橋本俊一 - 三村和弘 - 郡田和彦 : 鉄と鋼, 71-16(1985), 1949-1955.

3）日本塑性加工学会編 : せん断加工，(2000), 87, コロナ 社.

4）岩谷二郎・岡野洋一郎・上野行一 : 神戸製鋼技報， 47-2 (1997), 33-37.

5) 日本塑性加工学会編 : せん断加工，(2000)，11，コロナ 社.

6) Hancock, J.W. \& Mackenzie, A.C. : Journal of the Mechanics and Physics of Solids, 24-2(1976), 147-160.

7) 島貫広志 - 古谷仁 - 井上建裕 - 萩原行人 - 豊田政男 : 日本造船学会論文集，186(1999)，475-483.

8) 吉成仁志 - 榎並啓太郎 - 管満春 - 金田重裕 : 材料, 54-3(2005), 296-301.

9) 中川威雄・阿部邦雄・林豊: 薄板のプレス加工, (2001), 182-195, 実教出版社. 